\title{
Komunikacja Grupy Filmowej Darwin w serwisie społecznościowym YouTube
}

\begin{abstract}
Streszczenie
W artykule przedstawiono analizę badań własnych dotyczących komunikacji w serwisie społecznościouym YouTube kanału „Grupa Filmowa Daruin”, określanego w internecie mianem najbardziej profesjonalnego profilu na polskim YouTubie. Skupiono się przede uszystkim na badaniu zachowania widzów oraz odbiorze działalności kanału przez skupioną wokół niego społeczność. Celem badania jest spraudzenie, jak na działania i formaty wideo przygotouywane przez uybrany kanał YouTube reaguje publiczność internetowa, a także próba określenia wartościouych zachowań twórców, budujących wokół siebie duże grupy odbiorców.
\end{abstract}

Słowa kluczowe: Grupa Filmowa Darwin, YouTube, komunikacja, media społecznościowe, społeczność.

\section{Communication of the Grupa Filmowa Darwin on YouTube}

\section{Abstract}

The article presents an analysis of personal research on communication of Grupa Filmowa Darwin YouTube channel, defined in the Internet as the most professional profile on Polish YouTube. The author analyses patterns of viewers behaviour and their reactions to uploaded on channel content. The aim of the study is to evaluate how the Internet audience reacts to the actions and video formats prepared by the chosen YouTube channel and make an attempt to determine valuable features of authors who gathers large communities of recipients.

Keywords: Grupa Filmowa Darwin, YouTube, communication, social media, community.

\section{Wprowadzenie}

Obecność w „Interbrand: The Best Global Brands” to marzenie każdego tuórcy marki niezależnie od tego, z czym byłaby ona związana i gdzie kreowana. Nic w tym dziunego, mowa przecież o jednym z najbardziej prestiżouych rankingów marek światowych ${ }^{1}$. Oczywiście nie każdy ma szansę znaleźć się w takim zestawieniu, chociażby dlatego, że wskazuje on jedynie na stu najlepszych z najlepszych. Mowa bowiem o liderach,

1 J. Kall, B. Sojkin, Zarzadzanie produktem: kreowanie marki, Wydawnictwo Uniwersytetu Ekonomicznego, Poznań 2010, s. 157. 
obecnych na światouym rynku od wielu lat. Na przykład w roku 2016 na pieruszych pięciu pozycjach rankingu uklasyfikowały się kolejno marki: Apple, Google, Coca-Cola, Microsoft i Toyota ${ }^{2}$. Ważne jest jednak to, by wiedzieć, jak dojść do tak dużego sukcesu i przełożyć to na skalę, na której się działa. Nawet jeśli nigdy nie uda się znaleźć uśród najlepszych marek, umiejętność kreowania właściwej komunikacji wciąż jest kluczowa dla komercyjnego sukcesu w dzisiejszych czasach. Jednym z miejsc w internecie, które pozwala na rozpoczęcie procesu kreowania siebie na markę jest serwis YouTube. Kiedy portal ten rozpoczynał swoją działalność w roku 2005, była to jedna z wielu stron internetowych, której - jak piszą Jean Burgess i Joshua Green w książce YouTube: wideo online a kultura uczestnictwa - celem było umożliwienie współdzielenia się treściami multimedialnymi $w$ internecie ${ }^{3}$. Minęło jednak wiele lat, w czasie których serwis stał się największą tego typu platformą na świecie i dziś dużo lepszą jego definicją wydaje się ta zaproponowana przez Jeffreya Gitomera, który pisze: „YouTube to najlepsza okazja na promocję własnego nazwiska i kreowanie własnej marki”. Serwis jest zresztą bardzo podobnie pojmowany w Polsce, o czym świadczy chociażby artykuł Agnieszki Kalinouskiej i Marcina Pieńkouskiego w „Rzeczpospolitej”. Omawiając podstawowe założenia serwisu YouTube, piszą oni, że istota aktywności u tym serwisie polega na „założeniu ułasnego kanału, który wraz ze wzrostem popularności staje się autonomiczną marką"4.

Jednym z takich kanałów-marek jest profil Grupa Filmowa Darwin, istniejący na YouTubie od 14 stycznia 2015 roku $^{5}$ i uspółtworzony przez duóch absoluentów Krakouskiej Państwowej Wyższej Szkoły Teatralnej, Marka Hucza i Jana Jurkouskiego. Warto uspomnieć, że nie jest to pierwszy kanał wymienionych twórców - wcześniej współprowadzili oni profil istniejący od 9 października $2012 \mathrm{roku}^{6}$ pod tą samą nazwą, który w późniejszym czasie - gdy autorzy zdecydowali się na nowy etap swojej działalności - został przemianowany na Archiurum Darwina i zamknięty dla publikowania nowych treści. W październiku 2018 roku kanał Grupa Filmowa Daruin znajdował się na 118 pozycji w rankingu ApyNews z liczbą 626770 subskrybentów oraz 87707113 uyświetleń (dane z dnia 4 października 2018 roku). Zdecydowano się na wybór tego kanału mimo dzielących go 117 miejsc od lidera rankingu, czyli konta Blowek $^{8}$ ze względu na opinię $\mathrm{w}$ internecie.

\footnotetext{
${ }_{2}$ Best Global Brands 2016 Rankings, http://interbrand.com/best-brands/best-global-brands/2016/ranking/ (dostęp: 04.10.2018).

3 J. Burgess, J. Green, YouTube: wideo online a kultura uczestnictwa, tłum. T. Płudouski, Wydawnictuo Naukowe PWN, Warszawa 2011, s. 23.

${ }^{4}$ A. Kalinowska, M. Pieńkouski, YouTube, czyli nowa forma życia, „Rzeczpospolita” 2015, nr 195, s. 7.

${ }^{5}$ G.F. Darwin, Informacje, https://wuw.youtube.com/channel/UCkPjHTuNd_ycm__29d XM3Nu/about (dostęp: 04.10.2018).

${ }^{6}$ Archiuum Darwina, Informacje, https://www.youtube.com/user/grupafilmowadarwin/about (dostęp: 04.10.2018).

${ }_{7}$ ApyNews, Ranking YouTube, https://apynews.pl/ranking-youtuberow?sort=c.subscriberCount\&direction=DESC\&page $=2$ (dostęp: 04.10.2018).

${ }^{8}$ Ibidem.
} 
Komunikacja Grupy Filmowej Darwin w serwisie społecznościowym YouTube

\title{
Google najbardziej profesjonalny kanał na polskim YouTube

Wszystko Filmy Grafika Wiadomości Mapy Więcej Ustawienia Narzędzia \\ Około 293000 wyników $(0,28 \mathrm{~s})$
}

Grupa Filmowa Darwin to najbardziej profesjonalny kanał na polskiej ... natemat.pl $>$ Władcy Sieci $~-$

22 kwi 2015 - Grupa Filmowa Darwin to najbardziej profesjonalny kanał na polskiej scenie YouTube

Tworzą go ludzie związani z filmem i wychodzi im to

\begin{abstract}
Grupa Filmowa Darwin. "Najbardziej profesjonalny kanał YouTube ... www.polskieradio.pl/.../1494179,Grupa-Filmowa-Darwin-Najbardziej-profesjonalny-... . 26 sie 2015 - "Aktorstwo to taki mały sens życia" - powiedział niegdyś Jan Jurkowski z Grupy Filmowej Darwin. W Czwórce wyjaśnia, co miał na myśli.
\end{abstract}

Grupa Filmowa Darwin -najbardziej profesjonalny kanał na Youtube w ... https://www.wykop.pl/...grupa-filmowa-darwin-najbardziej-profesjonalny-kanal-na-y... . 19 gru 2015 - Dobrze nam znana Grupa Filmowa Darwin została doceniona w mediach. "...to najbardziej profesjonalny kanał na polskiej scenie YouTube.

Profile Youtuberów - Bio polskich twórców internetowych - APYnews https://apynews.pl/bio-youtuberow $\mathbf{v}$

Jeden z naczelnych dowcipnisiów polskiego YouTube' to z pewnością Naruciak ..... która jest uważana za najbardziej profesjonalny kanał na polskim YouTubie.

Rycina 1. Zrzut ekranu prezentujący wyniki wyszukiwania frazy „najbardziej profesjonalny kanał na polskim YouTube" w wyszukiwarce Google ${ }^{9}$

Wpisanie w wyszukiwarkę Google frazy „najbardziej profesjonalny kanał na polskim YouTube" nie pozostawia wątpliwości na temat jego reputacji w sieci - Grupa Filmowa Darwin jest określana tym mianem przez wiele polskich serwisów, wśród których zgodnie z kolejnością wyśuietlanych wyników w Google - można uymienić między innymi strony: natemat.pl, polskieradio.pl, wykop.pl czy apynews.pl.

Celem badania jest sprawdzenie, w jaki sposób publiczność skupiona wokół kanału Grupy Filmowej Darwin na niego trafiła, a także jak reaguje na jego działalność oraz przygotowywane przez twórców treści. Zdaniem autora wyniki badania mogą stać się cenną uskazówką dla przyszłych twórców oraz osób zajmujących się zagadnieniem kreowania marki na YouTubie.

Badanie na temat odbioru działalności Grupy Filmowej Darwin oraz podstawowej analizy zachowania społeczności widzów zostało wykonane w styczniu 2018 roku ${ }^{10}$ przy wykorzystaniu Survio.com, narzędzia pozwalającego na anonimowe przeprowadzanie ankiet online. W badaniu udział wzięło 1000 osób, będących w dużej części widownią

${ }_{9}^{9}$ Google, wynik wyszukiwania: najbardziej profesjonalny kanat na polskim YouTube, https://www.google.pl/search?q=najbardziej+profesjonalny+kana\%C5\%82+na+polskim +YouTube\&rlz=1C1GCEA_enPL781PL781\&oq=najbardziej+profesjonalny+kana\%C5\%82 + na+polskim + YouTube\&aqs=chrome..69i57.423j0j4\&sourceid $=$ chrome\&ie $=U T F-8$ (dostęp: 04.10.2018).

${ }^{10}$ Grupa Filmowa Darwin (Ankieta przeprowadzona przy wykorzystaniu narzędzia Survio.com), https://www.survio.com/survey/d/D1N8V1H8T5G6Y1H6C (dostęp: 04.10.2018). 
Grupy Filmowej Darwin obecną na grupie na Facebooku Darwiniści ${ }^{11}$ oraz osób, do których ankieta dotarła w sposób organiczny. Pierusze z pytań zawartych w ankiecie: „Czy zna Pan/Pani youtube'ouy kanał Grupy Filmowej Darwin”, nie miało na celu zbadania popularności kanału (a z uwagi na obecność ankiety na grupie Darwiniści uręcz nie może być tak traktowane), a jedynie pozwolić na szybsze zakończenie uypełniania kuestionariusza osobom, które nie będą w stanie udzielić odpowiedzi na kolejne pytania.

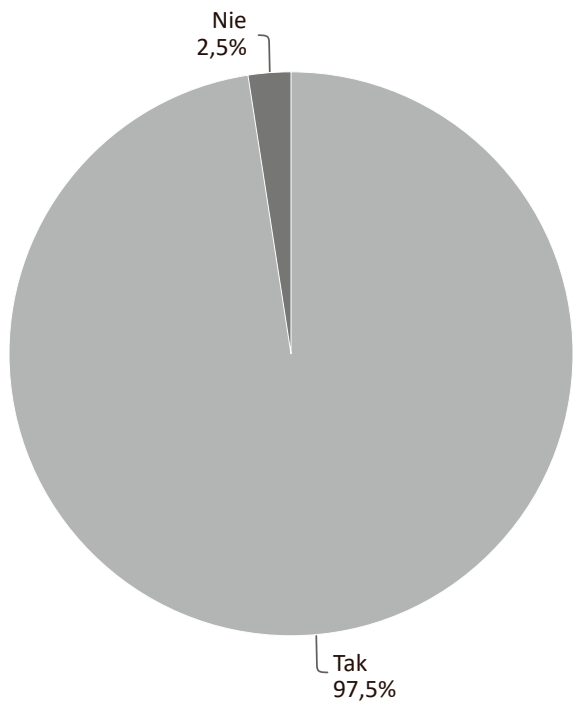

Rycina 2. Odpouiedzi respondentów na pytanie: „Czy zna Pan/Pani youtube’ouy kanał Grupy Filmowej Daruin?"

Źródło: badanie własne.

Zgodnie z zaprezentowanym wynikiem badania 97,5\% (975) respondentów zna kanał Grupy Filmowej Daruin (rycina 2), co oznacza, że będzie również w stanie odpowiedzieć na kolejne pytania z ankiety.

Podobny cel miało pytanie numer dwa: „Czy kiedykolwiek oglądał/a Pan/Pani filmy zamieszczane przez Grupę Filmową Darwin?”. Założono w tym przypadku, że znajomość samej nazuy grupy nie jest tożsama ze znajomością jej twórczości. Okazało się, że mimo sugestii przejścia do pytania z metryczką po odpowiedzi „Nie” w pytaniu pieruszym, część osób mimo wszystko odpowiedziała również na pytanie numer dua (12 respondentów). Jak wynika z przeprowadzonego badania, wśród wszystkich respondentów znalazły się 3 osoby, które słyszały o Grupie Filmowej Darwin, ale nigdy nie obejrzały żadnego z jej filmów (rycina 3).

${ }^{11}$ Darwiniści (Facebook), https://www.facebook.com/groups/darwinisci/ (dostęp: 04.10.2018). 
Komunikacja Grupy Filmowej Darwin w serwisie społecznościowym YouTube

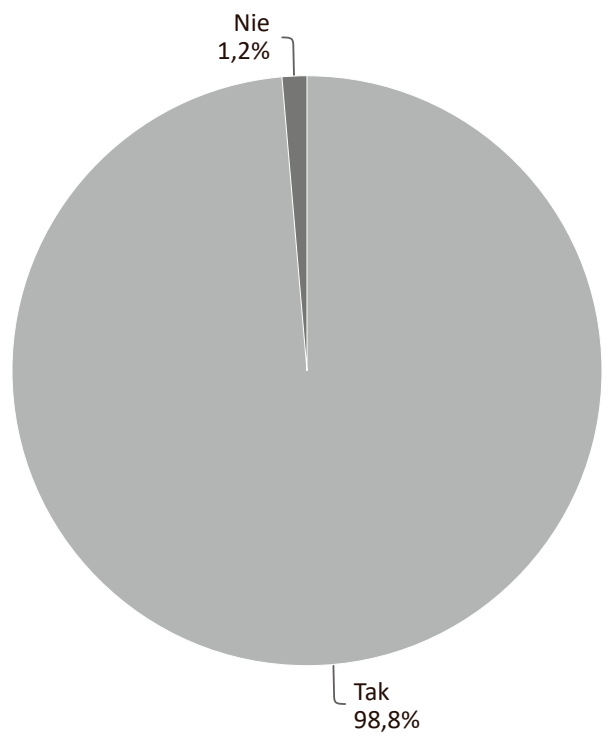

Rycina 3. Odpowiedzi respondentów na pytanie: „Czy kiedykolwiek oglądał/a Pan/Pani filmy zamieszczane przez Grupę Filmową Darwin?"

Źródło: badanie własne.

\section{Charakterystyka badanej zbiorowości}

Niezuykle istotna u przypadku badań mediów społecznościowych jest także grupa docelowa.

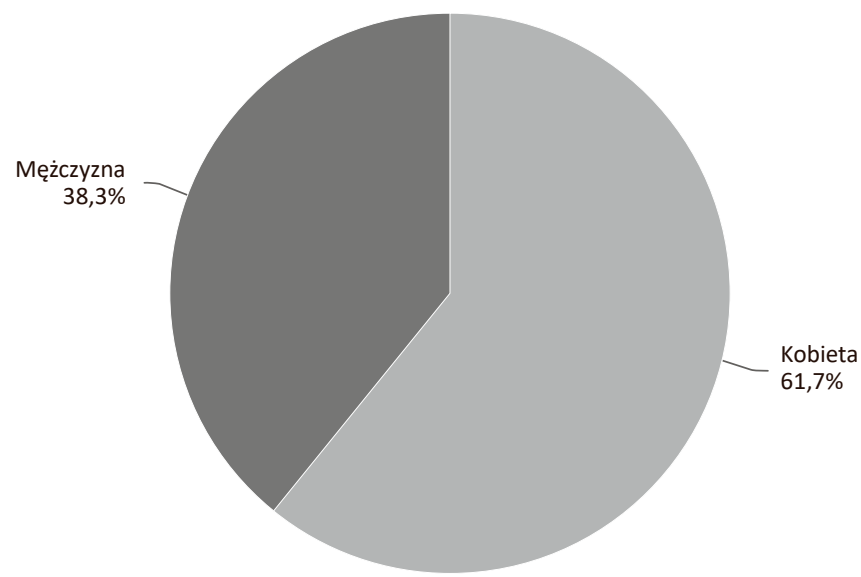

Rycina 4. Rozkład procentouvy respondentów według kryterium płci Źródło: badanie własne. 
Na podstawie przeprowadzonego badania stuierdzono, że u grupie 1000 przebadanych osób 61,7\% (617 respondentów) stanowią kobiety, a 38,3\% (383 respondentów) mężczyźni (rycina 4).

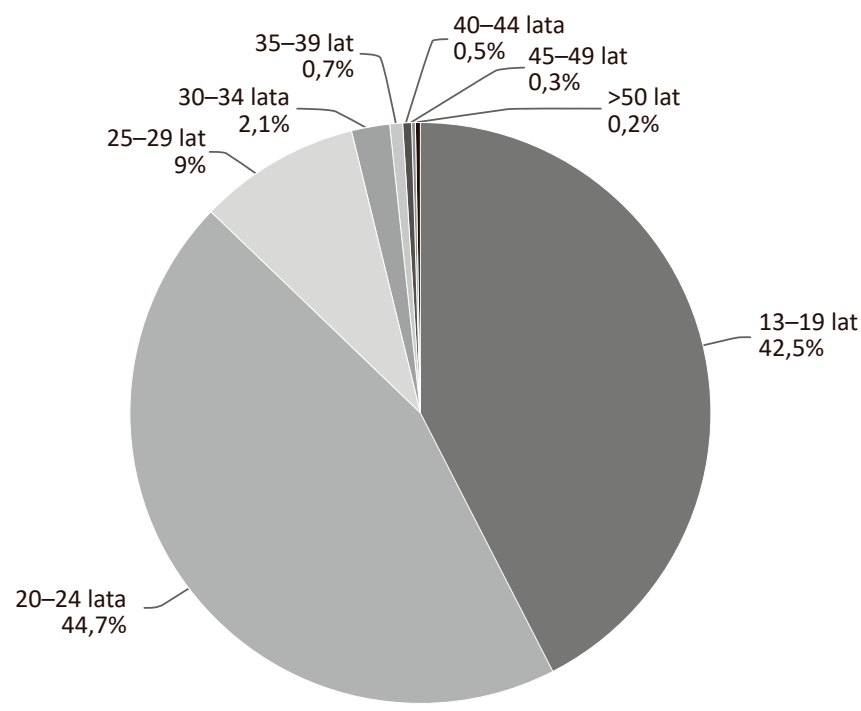

Rycina 5. Rozkład procentouy respondentów według kryterium wieku Źródło: badanie własne.

Analizując wiek respondentów, można zauważyć, że przeważające grupy wiekowe biorące udział $w$ badaniu to osoby w przedziale 20-24 lata (44,7\% - 447 osób) oraz 13-19 lat (42,5\% - 425 osób). Znaczącą dla badania grupę stanowią też osoby w wieku 25-29 lat (9\% - 90 osób) oraz 30-34 lata (2,1\% - 21 osób). Pozostali ankietowani to 7 osób (0,7\%) w wieku 35-39 lat, 5 osób (0,5\%) w wieku 40-44 lata, 3 osoby (0,3\%) w wieku 45-49 lat oraz 2 osoby pouyżej 50. roku życia (0,2\%) (rycina 5).

Chcąc dokonać głębszej analizy respondentów, opracowano tabelę krzyżową dopasowującą wiek do płci badanych osób. Wynika z niej, że aż 38,8\% kobiet udzielających odpowiedzi mieści się w przedziale wiekowym 13-19 lat, 48,4\% w przedziale 20-24 lata i 9\% w przedziale 25-29 lat. Pozostałe grupy wiekowe to 3,5\% wszystkich kobiet biorących udział w badaniu (tabela 1).

Podobnie sytuacja wygląda z grupą badanych mężczyzn, choć w przeciwieństwie do kobiet (najliczniejszą grupą była ta w przedziale 20-24 lata). Tym razem najwięcej osób stanowi grupa wiekowa 13-19 lat i jest to 48,3\% uszystkich przebadanych mężczyzn. Spośród badanych mężczyzn 38,6\% to osoby w wieku 20-24 lata, 8\% w wieku 25-29 lat i 4\% to pozostałe grupy wiekowe wszystkich mężczyzn biorący udział w badaniu (tabela 1 ). 
Komunikacja Grupy Filmowej Darwin w serwisie społecznościowym YouTube

Tabela 1. Tabela krzyżowa / płeć * wiek badanych osób

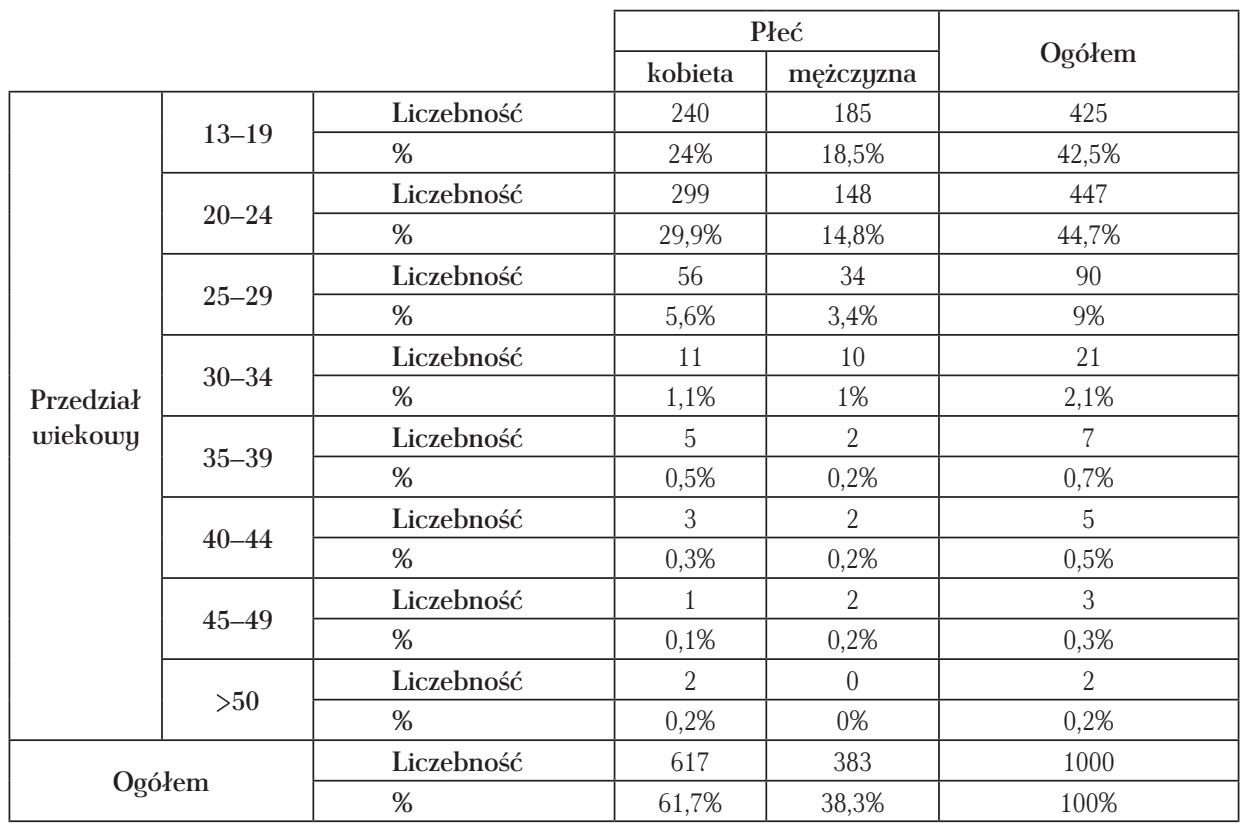

Źródło: badanie własne.

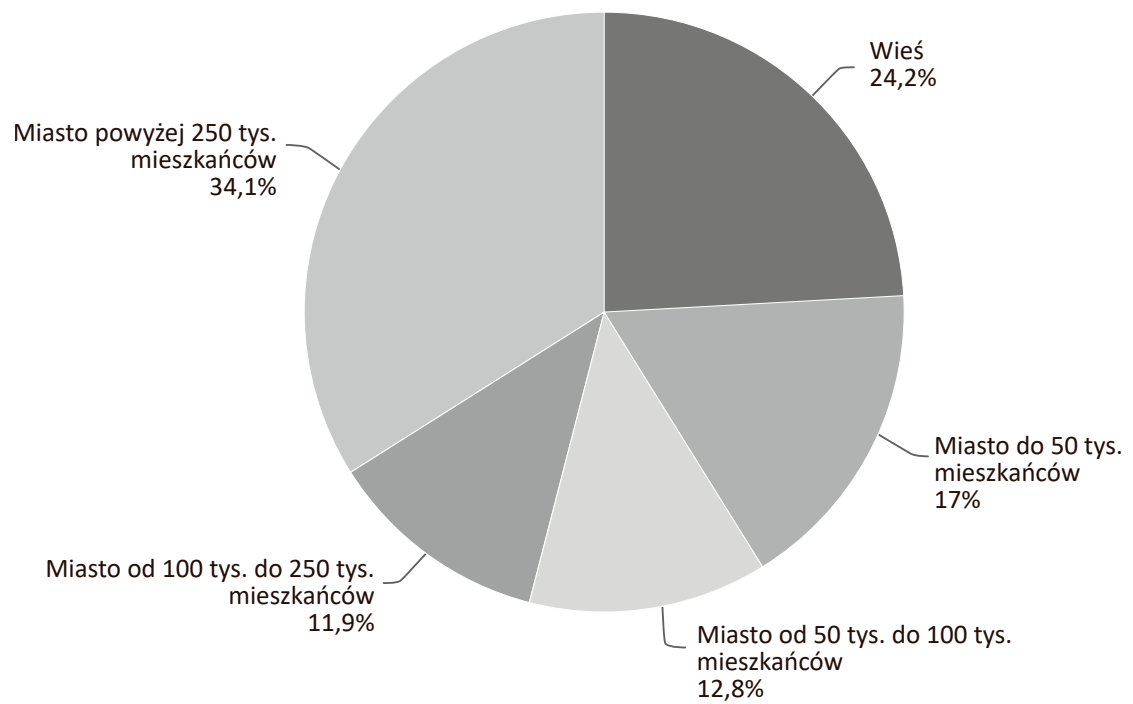

Rycina 6. Rozkład procentouy respondentów według kryterium miejsca zamieszkania Źródło: badanie własne.

Z analizy miejsca zamieszkania respondentów wynika, że największą grupę badanych stanowią osoby z miast o wielkości powyżej 250 tysięcy mieszkańców (34,1\%, czyli 341 osób), na drugim miejscu pod uzględem liczebności klasyfikują się mieszkańcy usi 
(24,2\%, czyli 242 osoby), a na kolejnych pozycjach miasta do 50 tysięcy mieszkańców (17\%, czyli 170 osoby), miasta od 50 tysięcy do 100 tys ięcy mieszkańców (12,8\%, czyli 128 osób) oraz miasta od 100 tys. do 250 tysięcy mieszkańców (11,9\%, czyli 119 osób) (rycina 6).

\section{Zachowania społeczności widzów Grupy Filmowej Darwin}

Podstawouym zagadnieniem pozwalającym zanalizować źródło popularności kanału Grupy Filmowej Darwin jest to, w jaki sposób widzowie trafili na dany profil na YouTubie. Postawiono więc osobom ankietowanym pytanie: „W jaki sposób trafił/a Pan/Pani na kanał Grupy Filmowej Darwin?".

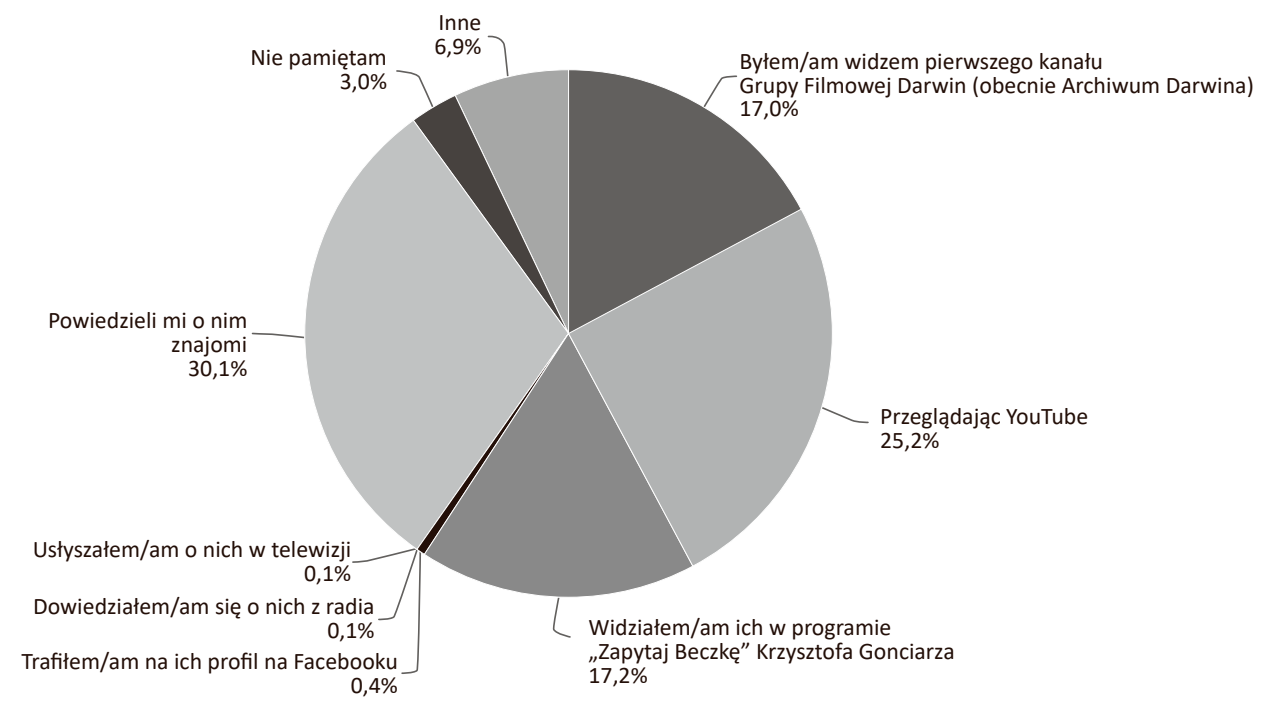

Rycina 7. Odpowiedzi respondentóu na pytanie: „W jaki sposób trafił/a Pan/Pani na kanał Grupy Filmowej Darwin?"

Źródło: badanie ułasne.

Aktualny kanał ma kilka głównych źródeł napływu widzów, spośród których najpopularniejsze to polecanie kanału przez znajomych, zaznaczone w kwestionariuszu przez 30,1\% ankietowanych, czyli 296 osób. Niewiele mniej widzów to osoby, które natrafily na kanał przypadkiem podczas przeglądania serwisu YouTube - mowa tu o 25,2\% ankietowanych (247 osób). Co ciekawe, prawie taka sama liczba widzów deklaruje znajomość kanału z programu „Zapytaj Beczkę” Krzysztofa Gonciarza, w którym Grupa Filmowa Darwin pojawiła się gościnnie w jednym z odcinków jeszcze podczas prowadzenia dzisiejszego Archiurum Darwina ${ }^{12}$ (17,2\% - 169 osób), jak migrację podczas

12 Zapytaj Beczkę, Nagrody Darwina - Zapytaj Beczkę \#103, https://www.youtube.com/ watch?v=GKtkhHGkGLg (dostęp: 04.10.2018). 
tworzenia nowego kanału i zamykania uspomnianego we ustępie kanału Archiwum Darwina (17\% - 167 osób). Praktycznie bez znaczenia dla napływu nouych widzów na kanał Grupy Filmowej Darwin na YouTube ma ich profil na Facebooku - tylko 4 ankietowanych $(0,4 \%)$ stwierdziło, że w ten sposób dowiedziało się o twórcach. Jeszcze mniej, bo tylko 0,2\% widzów, zna kanał z mediów tradycyjnych (radio lub telewizja) (rycina 7).

Jako ciekawostkę można potraktować fakt wiążący się z pytaniem: „Czy słyszał/a Pan/Pani o pieruszym kanale Grupy Filmowej Darwin, istniejącym aktualnie pod nazwą Archiwum Darwina?".

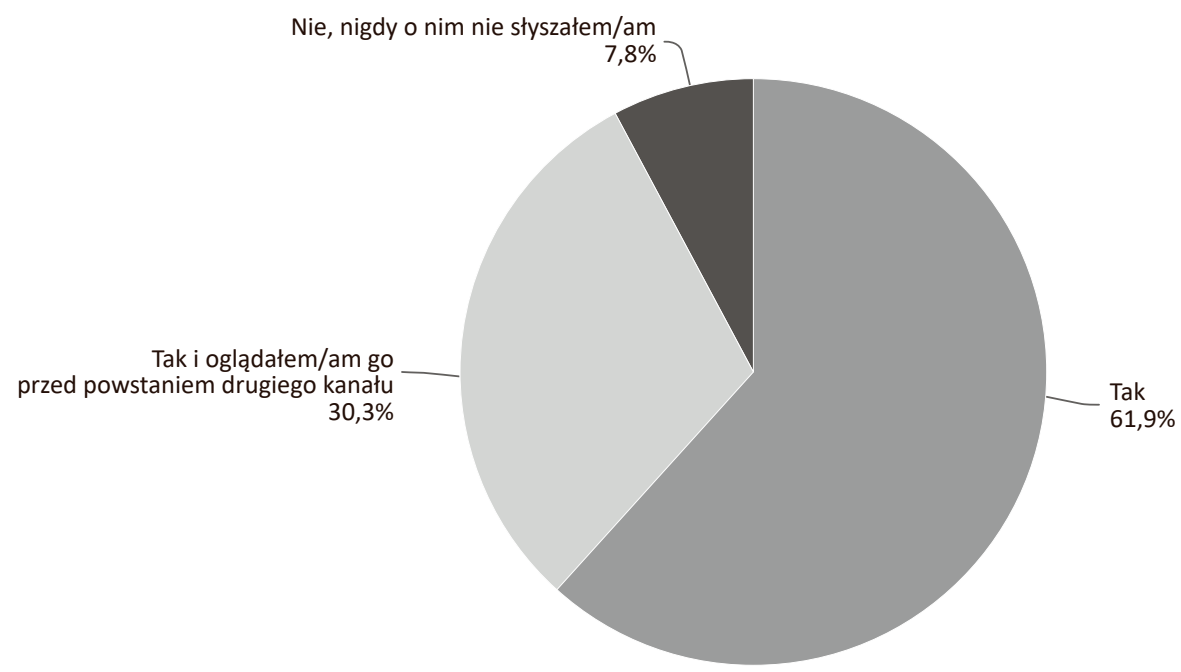

Rycina 8. Odpowiedzi respondentów na pytanie: „Czy słyszał/a Pan/Pani o pieruszym kanale Grupy Filmowej Darwin, istniejącym aktualnie pod nazwą Archiwum Darwina?”

Źródło: badanie własne.

Jak wynika z badania, 30,3\% widzów (296 osób) kanału Grupy Filmowej Darwin słyszało o ucześniejszej działalności twórców na kanale istniejącym aktualnie pod nazwą Archiuum Daruina. Zanim poustał obecnie działający profil, aż 61,9\% (604 osoby) dowiedziało się o niej po zapoznaniu się z twórczością poustałą po otwarciu drugiego profilu na YouTubie. Co ciekawe, aż 7,8\% widzów (76 osób) nie trafiło na wcześniejszy kanał tuórców (rycina 8) - pomimo chociażby jego stałej obecności na pasku „Polecane kanały" dostępnym na stronie głóunej profilu.

Interesujące wnioski nasuwają się po przeanalizowaniu odpowiedzi na pytanie: „Jakie media społecznościowe Grupy Filmowej Darwin Pan/Pani obseruruje?”. 


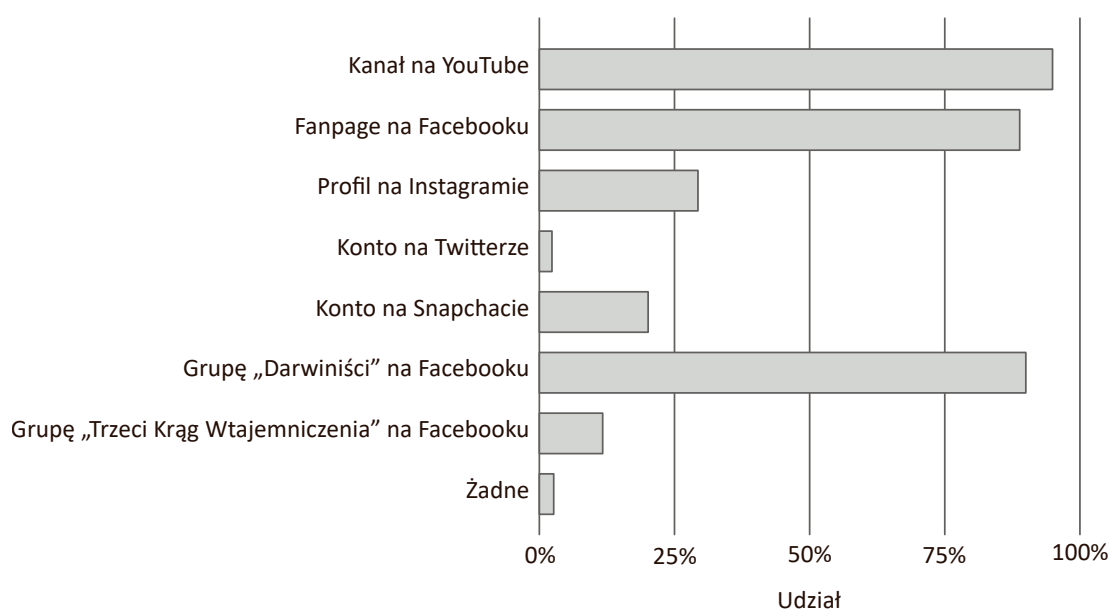

Rycina 9. Odpowiedzi respondentóu na pytanie: „Jakie media społecznościowe Grupy Filmowej Daruin Pan/Pani obserwuje?"

Źródło: badanie własne.

Jak wynika z odpowiedzi respondentów, zdecydowana większość widzów to subskrybenci kanału Grupy Filmowej na YouTubie (95,6\% - 939 osób) oraz obserwujący profil na Facebooku (89,3\% - 877 osób). Duża część próby tego badania pochodzi z grupy „Darwiniści” na Facebooku, co widoczne jest róunież uśród wyników kwestionariusza - suoją obecność na grupie deklaruje 90,5\% ankietowanych (889 osób). Oznacza to, że - wbrew pozorom - grupa na Facebooku jest mimo wszystko ciekauszym miejscem dla społeczności skupionej wokół kanału niż oficjalny profil twórców na Facebooku - różnica w obseruujących niniejsze media społecznościowe uynosi 12 osób (rycina 9). Na podstawie analizy krzyżowej wyników ankiety stwierdzono, że tak naprawdę aż 50 osób obserwujących grupę „Darwiniści” na Facebooku nie śledzi fanpage’a Grupy Filmowej Daruin. W tym kontekście warto róunież zwrócić uwagę na fakt, że pomimo wysokiego zaangażowania społeczności, jakim niewątpliwie jest obecność na oficjalnej grupie tuórców, kanały takie jak Instagram (29,5\%, czyli 290 obserurujących ankietowanych) czy Snapchat (20,4\%, czyli 200 obserwujących ankietowanych) (rycina 9) nie są dla społeczności aż tak ciekawe i angażujące. Nawet wśród 11,8\% (116 osób), które są na tyle zżyte z twórcami, że znajdują się w zamkniętej społeczności „Trzeci Krąg Wtajemniczenia" na Facebooku (dostępnej dla osób uspierających kanał u serwisie Patronite ${ }^{13}$ ), a więc są też Patronami twórców, Instagram jest kanałem obserwowanym tylko przez 59 osób, czyli 50,8\% Patronów, a Snapchat przez 35 osób, czyli 30,1\% Patronów. Konto na Tuitterze jest najmniej popularnym medium społecznościouym - obserwuje je tylko 2,3\% ankietowanych (23 osoby) (rycina 9). Z pewnością duży upływ ma na to fakt, że jego prowadzenie zostało zawieszone, a ostatni wpis ukazał się 8 listopada $2016 \mathrm{roku}^{14}$.

${ }_{13}$ Patronite, Grupa Filmowa Darwin, https://patronite.pl/darwin (dostęp: 04.10.2018).

14 Darwin, https://twitter.com/GFDarwin/status/795994130207936512 (dostęp: 04.10.2018). 
W ramach analizy zachowania społeczności widzóu zdecydowano się też na zadanie pytania: „Czy wie Pan/Pani o obecności Grupy Filmowej Darwin na platformie Patronite.pl?”. Mowa tu platformie, dzięki której tak zuani Autorzy mogą otrzymywać comiesięczne wsparcie finansowe od Patronów, czyli współczesnych mecenasów kultury w internecie ${ }^{15}$.

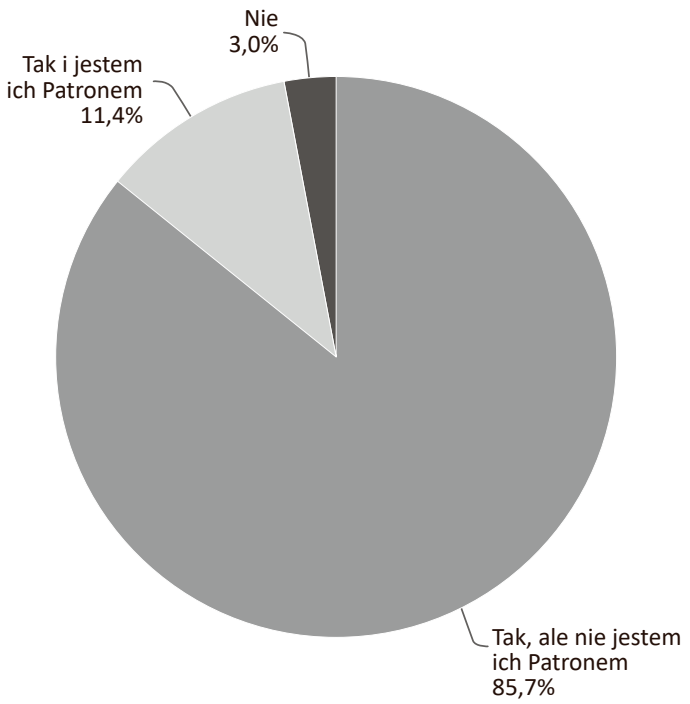

Rycina 10. Odpowiedzi respondentów na pytanie: „Czy wie Pan/Pani o obecności Grupy Filmowej Darwin na platformie Patronite.pl?"

Źródło: badanie własne.

Jak się okazuje, większość widzów kanału, bo aż 97\% społeczności, jest świadoma obecności Grupy Filmowej Darwin u serwisie Patronite, z czego aż 11,7\% (111 osób) jest przy tym Patronem twórców (rycina 10). Głębsza analiza krzyżowa wyników pozuala stuierdzić, ile dokładnie osób spośród Patronów Grupy Filmowej Darwin mieści się w poszczególnych przedziałach wiekouych. W grupie 13-19 lat znajduje się 42 patronów (37,8\%) - w tym 8 kobiet i 34 mężczyzn; grupa 20-24 lata to 46 patronów $(41,4 \%)$ - w tym 33 kobiety i 13 mężczyzn; grupa 25-29 lat to 12 patronów (10,8\%) - w tym 4 kobiety i 8 mężczyzn; grupa 30-34 lata to 4 patronów (2,7\%) - uszyscy to kobiety; grupa 35-39 lat to róunież 4 patronów (2,7\%) - uszyscy to kobiety; grupa $45-49$ lat to 1 mężczyzna $(0,9 \%)$ i grupa powyżej 50 . roku życia to 2 kobiety $(1,8 \%)^{16}$.

15 Patronite, Jak działa Patronite, https://patronite.pl/jak_to_dziala (dostęp: 04.10.2018).

${ }^{16}$ Własna analiza krzyżowa wyników ankiet. 


\section{Odbiór działalności Grupy Filmowej Darwin wśród badanej zbiorowości}

W ramach analizy odbioru twórczości Grupy Filmowej Darwin zbadano trzy zagadnienia, które pozwalają stuierdzić, co widowni się w niej podoba, a co wymaga poprawy. W pieruszym z pytań z tej serii poproszono respondentów o ocenienie, które z serii filmowych publikowanych na kanale są najbardziej lubiane, a które najmniej. Respondenci oceniali cykle, dopasourując do nich cyfry od 1 do 6, gdzie 1 to seria najbardziej lubiana, a 6 najmniej. W badaniu piosenki „Orki z Majorki” oraz „Kluski” zostały wyodrębnione z cyklu, do którego zaklasyfikowali je twórcy (,Shorty Darwina”) i przydzielone do oddzielnej serii nazwanej przez autora Piosenkami Grupy Filmowej Daruin - z uwagi na specyfikę tego typu materiałów i ich wysoką popularność nawet względem pozostałych filmów.

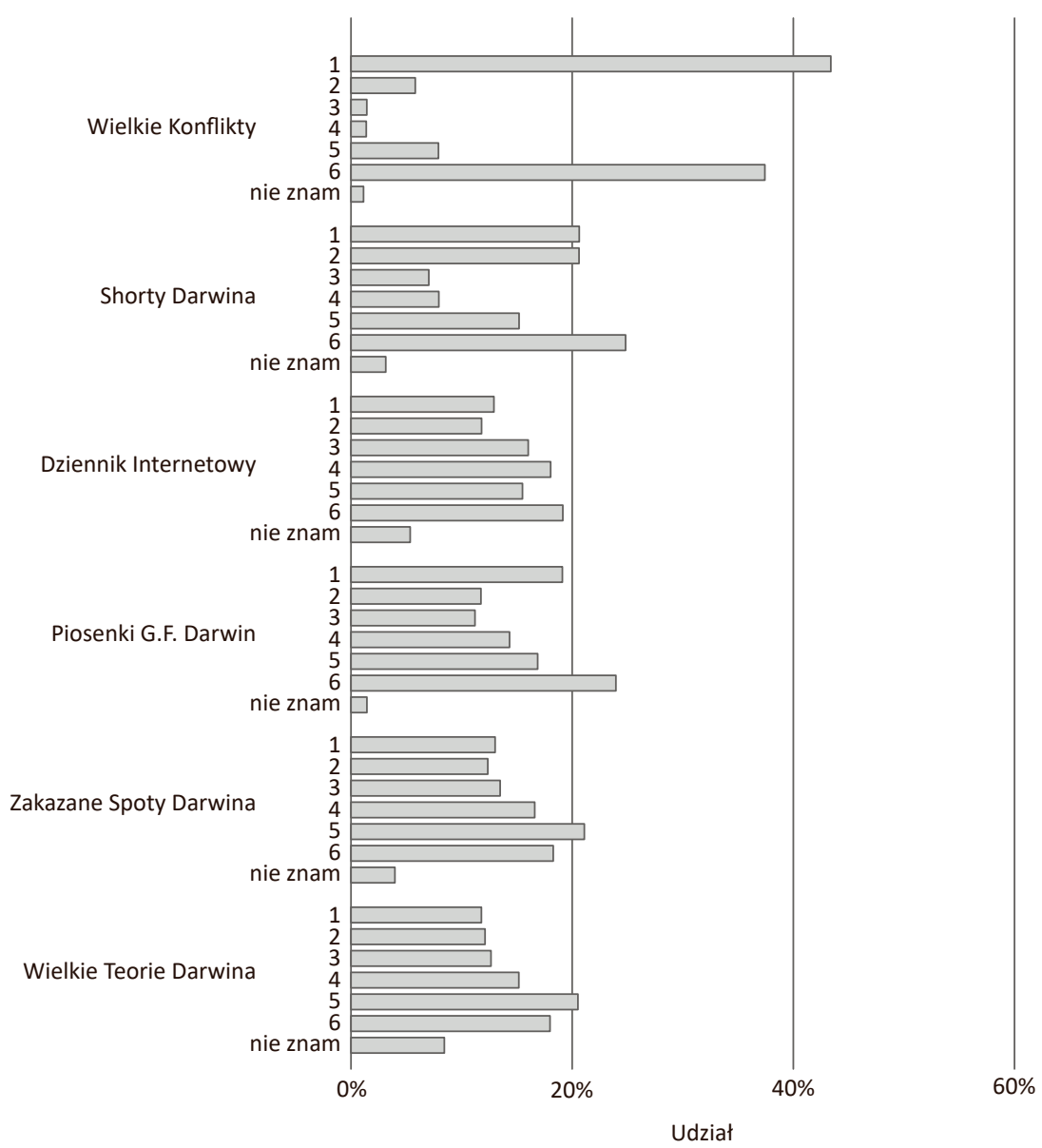

Rycina 11. Odpowiedzi respondentóu na polecenie: „Proszę przypisać seriom Grupy Filmowej Darwin miejsca od najbardziej przez Pana/Panią lubianej (1) do najmniej lubianej (6)" Źródło: badanie ułasne. 
Najbardziej lubianym cyklem jest seria „Wielkie Konflikty”, którą na pieruszym miejscu oznaczyło aż 426 respondentów (43,4\%). Róunież dość duża grupa osób przydzieliła tej serii dopiero 6 miejsce - mowa tu o 368 osobach, czyli 37,5\% ankietowanych (rycina 11). Zanim zostanie podjęta próba rozstrzygnięcia, jak faktycznie uygląda popularność poszczególnych serii, biorąc pod uwagę nie tylko skrajne wyniki (1 i 6), zaprezentowane zostaną kolejne liczby, uskazujące na pierwsze i ostatnie odpowiedzi respondentów. Drugie miejsce wśród najpopularniejszych serii filmowych należy do „Shortów Darwina”, które uzyskały 202 (20,6\%) pieruszych uskazań, ale też zostały ocenione aż 243 razy (24,8\%) jako seria najmniej lubiana. Trzecie miejsce to wyodrębnione przez autora Piosenki Grupy Filmowej Darwin, które zuycięskie podium zdobyły 189 razy (19,3\%) i najmniej lubiane 235 razy (24\%). Miejsce czwarte przypada seriom „Dziennik Internetouy” oraz „Zakazane Spoty Darwina” - obie zdobyly 128 pieruszych uskazań (13\%), a różnica uskazań jako seria najmniej lubiana to tylko 9 głosów („Dziennik Internetowy” z wynikiem 188 głosów, czyli 19,2\% i „Zakazane Spoty Darwina” - 179 głosów, czyli 18,2\%). Najmniej lubianą serią okazały się „Wielkie Teorie Darwina" zrealizowane we uspółpracy z platformą player.pl - jako swój ulubiony cykl uskazało ją 117 osób (11,9\%), a jako najmniej lubianą 178 (18,1\%) (rycina 11). Aby wykorzystać pozostałe wyniki, postanowiono stworzyć uzór, którego celem będzie sprawdzenie rzeczywistej popularności odcinków.

Tabela 2. Waga punktów przypisanych uskazaniom respondentów

\begin{tabular}{|l|c|c|c|c|c|c|}
\hline Wskazanie respondenta & 1 & 2 & 3 & 4 & 5 & 6 \\
\hline Waga punktów & 1 & 0,85 & 0,70 & 0,55 & 0,40 & 0,25 \\
\hline
\end{tabular}

Źródło: opracowanie ułasne.

Nadano każdemu z głosów wagę, a następnie przygotowano następujący wzór, który wykorzystywał również potencjał głosów ze uskazań miejsc od 2 do 5:

Końcoua liczba punktów $=[$ liczba uskazań miejsca $1 \times 1]+[$ liczba uskazań miejsca $2 \times 0,85]+[$ liczba uskazań miejsca $3 \times 0,70]+[$ liczba uskazań miejsca $4 \times 0,55]+$ [liczba uskazań miejsca $5 \times 0,40]+[$ liczba uskazań miejsca $6 \times 0,25]$.

Tabela 3. Popularność serii przy wzięciu pod uwagę uszystkich uskazań respondentów

\begin{tabular}{|l|c|c|c|}
\hline \multicolumn{1}{|c|}{ Nazwa serii } & Wynik ze wzoru & Miejsce ze wzoru & $\begin{array}{c}\text { Miejsce } \\
\text { z pierwszego } \\
\text { wskazania }\end{array}$ \\
\hline Wielkie Konflikty & 622,25 & 1 & 1 \\
\hline Shorty Darwina & 587,75 & 2 & 2 \\
\hline Dziennik Internetouy & 543,05 & 5 & 4 \\
\hline Piosenki Grupy Filmowej Darwin & 571,75 & 3 & 3 \\
\hline Zakazane Spoty Darwina & 544,9 & 4 & 4 \\
\hline Wielkie Teorie Darwina & 515,85 & 6 & 6 \\
\hline
\end{tabular}

Źródło: opracowanie własne. 
Jak się okazało, róunież po wzięciu pod uwagę uszystkich miejsc nadanych seriom przez ankietowanych, wynik jest praktycznie taki sam dla wszystkich serii - jedyna różnica to zróżnicowanie miejsc w rankingu dla serii „Dziennik Internetowy” oraz „Zakazane Spoty Darwina” z przewagą dla drugiej z nich.

W kolejnym pytaniu zadaniem ankietowanych było wskazanie jednego ulubionego filmu zrealizowanego przez Grupę Filmową Darwin - respondenci mieli możliwość upisania wyniku samodzielnie. Z odpowiedzi respondentów wynika, że najbardziej lubianym odcinkiem ze wszystkich wyprodukowanych przez Grupę Filmową Daruin do lutego 2018 roku jest film „C.H.A.O.S. - czyli początek uszystkiego!”, wskazany przez 94 osoby, czyli 9,97\% wszystkich, którzy udzielili odpowiedzi. Miejsce drugie zajął odcinek „Wielkie Konflikty - odc. 13 Hitler vs Sąd Ostateczny” - wskazany przez 77 osób (8,17\%), a miejsce trzecie film „Piekło 2.0” - wybrało go 36 osób (3,82\%). Wśród filmów, które również pojawiały się w odpowiedziach, wielokrotnie znalazły się także: „Wielkie Konflikty - odc. 21 Hiob vs Szatan” (26 głosów), „Wielkie Konflikty - odc. 4 Słowacki vs Mickiewicz” (24 głosy) oraz „Wielkie Konflikty - odc. 14 Balladyna vs Alina” (22 głosy). Co ciekawe, aż 118 osób, czyli 12,5\% ankietowanych zadeklarowało, że nie ma jednego ulubionego odcinka lub nie potrafi go wskazać spośród kilku uybranych.

Zadaniem ostatniego z pytań spraudzających odbiór działalności grupy było zueryfikowanie, jak oceniane przez widzów są poszczególne jej elementy. Ankietowani oceniali od 1 do 6 humor i powagę w filmach, jakość wideo oraz dźwięku, grę aktorską, charakteryzację, scenografię, profesjonalizm prowadzenia mediów społecznościouych, ciekawe przygotowanie treści sponsorowanych oraz częstotliwość publikacji.

Humor w filmach zdecydowana większość respondentów oceniła na najwyższy z możliwych sposobów - aż 732 osoby (74,5\%) przyznały twórcom ocenę 6 i 156 osób (15,9\%) ocenę 5. Ponadto 63 osoby (6,4\%) określiły tę cechę na najmniejszą możliwą notę (rycina 12). Powaga w filmach okazała się dla respondentów zagadnieniem polaryzującym zdania lub po prostu niedookreślonym - w tym pytaniu pojawiło się najwięcej rozbieżności:

- 41 (4,8\%) osób wystawiło w tym miejscu ocenę 1;

- 79 (8,1\%) osób - 2;

- $142(14,5 \%)$ osoby - 3;

- $201(20,5 \%)$ osób - 4;

- 199 (20,3\%) osób - 5;

- $212(21,6 \%)$ osób - 6 . 


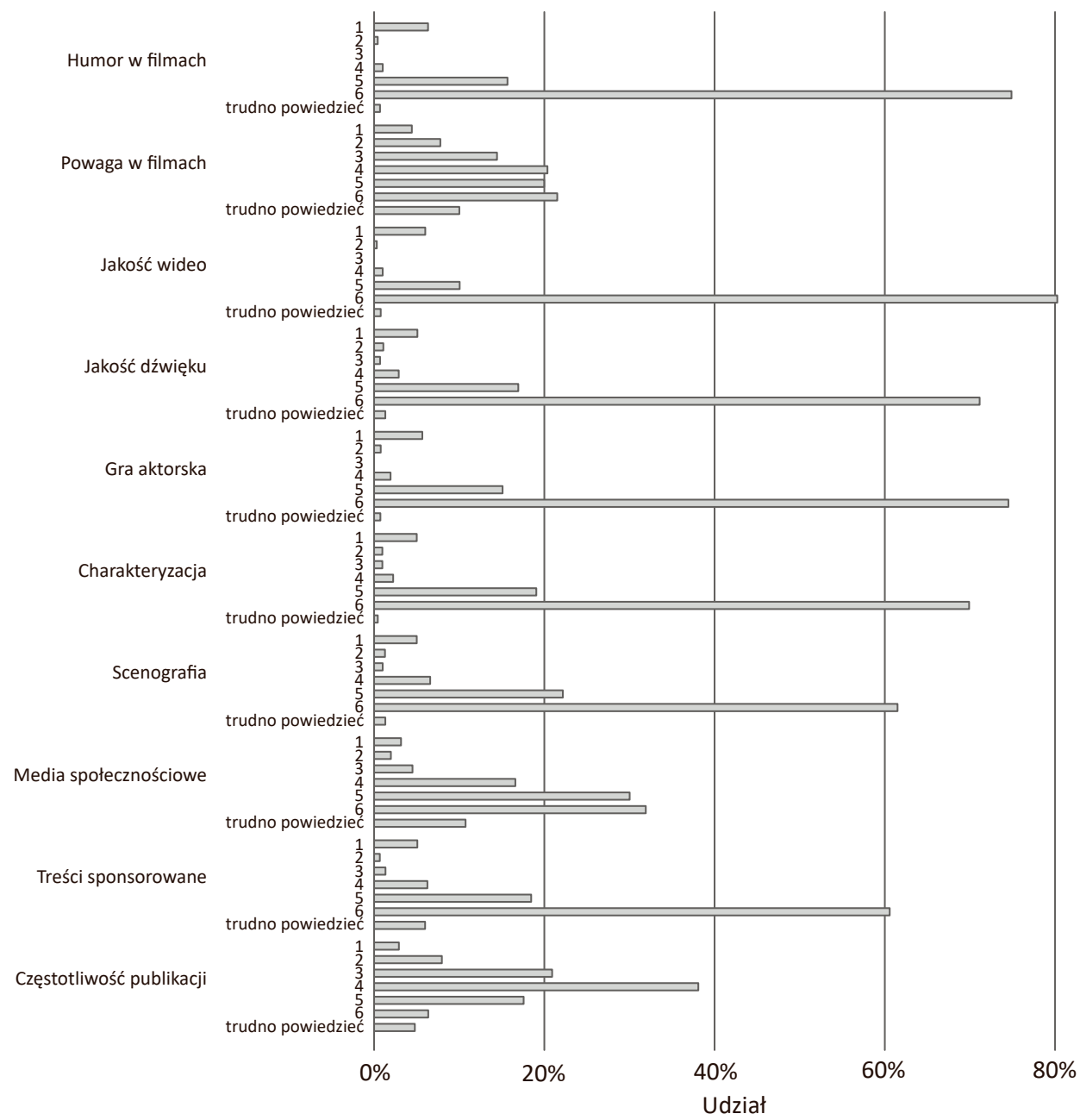

Rycina 12. Odpowiedzi respondentóu na polecenie: „Proszę ocenić u skali od 1 do 6 poszczególne cechy związane z działalnością Grupy Filmowej Darwin” Zródło: badanie własne.

Aż 99 osób (10,1\%) wskazało w tym pytaniu odpowiedź „Trudno pouiedzieć” (rycina 12). Ankietowani w większości przypadków zgodnie tuierdzą, że jakość obrazu w filmach Grupy Filmowej Darwin jest bardzo dobra i zasługuje na ocenę 5 - tak zagłosowało 100 osób (10,2\%) - lub znakomita - na ocenę 6 zagłosouało 790 osób (80,5\%). W tym przypadku najniższą notę przyznało twórcom 61 osób (6,2\%). Podobnie sytuacja wygląda w przypadku dźwięku - tutaj ocenę 5 wystawiło 168 osób $(17,1 \%)$ a ocenę 6 - 695 ankietowanych (70,8\%). W tym przypadku najniższą ocenę uskazało 51 osób (5,2\%). Równie dobrze respondenci oceniają grę aktorską (ocena 5 - 149 osób, 
czyli 15,2\%; ocena 6 - 730 osób, czyli 74,4\%), charakteryzację (ocena 5 - 189 osób, czyli 19,3\%; ocena 6 - 687 osób, czyli 70\%), scenografię (ocena 5 - 218 osób, czyli 22,2\%; ocena 6 - 602 osoby, czyli 61,4\%) oraz ciekawe przygotowanie treści sponsorowanych (ocena 5 - 184 osoby, czyli 18,8\%; ocena 6 - 594 osoby, czyli 60,6\%). Dużo gorzej wyniki rozkładają się w przypadku częstotliwości publikacji - w tym przypadku aż 206 (21\%) osób oceniło twórców na 3 i aż 375 osób (38,2\%) na 4. Ocenę 5 zaproponowały 174 osoby (17,7\%), a najwyższą jedynie 65 ankietowanych (6,6\%). Jeśli chodzi o profesjonalne prowadzenie mediów społecznościouych oceny róunież nie są tak jednoznaczne, jak w przypadku wymienionych wcześniej cech. Większość głosów mieści się u przedziale 4-6 (4 - 166 osób, czyli 16,9\%; 5 - 294 osoby, czyli 30\%; 6 - 314 osób, czyli 32\%). Jednak aż 106 ankietowanych (10,8\%) wybrało opcję „Trudno powiedzieć” (rycina 12), co oznacza, że jest to dla nich trudne do ocenienia lub po prostu nie śledzą żadnego z kanałów społecznościouych grupy.

Z analizy ankiety badawczej wynika, że seria „Wielkie Konflikty” jest najpopularniejszym cyklem na kanale Grupy Filmowej Daruin, co w pewnym sensie mogłoby być dla dalszych działań artystów zagrożeniem, zmuszającym ich do nieustannego kontynuowania jej dla utrzymania stałej grupy widzów. Dobrym znakiem jest natomiast fakt, że druga z serii (która zdecydowanie - chociażby biorąc pod uwagę liczbę publikowanych w jej obrębie odcinków - jest drugim z najważniejszych cykli), czyli „Shorty Darwina” jest także bardzo lubiana wśród widzów, a wręcz niejednokrotnie uskazywana jako ich zdaniem ważniejsza. Analiza ankiety pozuala róunież stuierdzić, że dobrym strategicznie krokiem ze strony twórców było przygotowanie odcinków „Shortów Darwina”, które ściśle korespondują z „Wielkimi Konfliktami”, ale mimo uszystko promują oddzielny segment działalności grupy. Dua z trzech najbardziej lubianych wśród społeczności materiałów należą bowiem do cyklu „Shortów Darwina” - nie da się jednak nie zurócić uwagi na ich ścisłe powiązanie z najpopularniejszą z serii. Tego typu rozwiązanie pozwala widzom poruszać się w obrębie swojego ulubionego uniwersum, a przy okazji - być może podświadomie uręcz - poznawać i oswajać się z odrębnym segmentem. To, co natomiast wydaje się największym wyzwaniem dla kanału, to próba zwiększenia częstotliwości produkcji odcinków, na którą najczęściej jako element do poprawy uskazują widzowie, a która z racji skomplikowanych procesów produkcyjnych i specyfiki kanału może być niemożliwa do zrealizowania.

\section{Zakończenie}

Celem artykułu było przyjrzenie się kanałowi Grupy Filmowej Darwin, określanemu jako najbardziej profesjonalny profil na polskim YouTubie i zbadanie działań oraz formatów wideo przygotowywanych przez twórców pod kątem reakcji na nie przez widzów, a także próba określenia wartościouych zachowań twórców, budujących kanał-markę. Z badań ankietowych przeprowadzonych przez autora wynika, że widzowie kanału Grupy Filmowej Darwin wielce cenią wysoką jakość techniczną 
publikowanych przez twórców filmów i jest to dla nich ważny aspekt podczas ich oglądania, do czego - jak wynika z obserwacji ogólnych trendów na YouTubie - duża część twórców nie przywiązuje aż tak dużej uwagi. Okazuje się również, że wbrew ogólnym przypuszczeniom zuiązanym z tym, że współprace marketingowe kanałów na YouTubie i marek komercyjnych nie są lubiane przez widzów, działania reklamowe prowadzone przez Grupę Filmową Darwin (segment Zakazane Spoty Darwina) są przez nich doceniane i oglądane równie chętnie jak pozostałe materiały zamieszczane na kanale. Ponadto gwarantują jednocześnie wartościouy materiał dla widza i zadowalające uyniki dla podmiotu komercyjnego zlecającego reklamę.

Ciekawostką jest fakt, że wbrew temu, co mogłoby się wydawać, prowadzenie przez twórców działających na YouTubie kanałów społecznościowych we wszystkich popularnych serwisach społecznościouych nie jest niezbędne do zyskania dużej widowni. Okazuje się wręcz, że często treści przygotowywane na kontach dodatkowych, takich jak Twitter, Instagram czy Snapchat, nie docierają do większości widzów kanału na YouTubie. Wyjątkiem jest tu Facebook, który okazuje się najważniejszym medium uspierającym, jednak również dopiero w momencie, gdy poznają oni już właściuy główny profil autora na YouTubie. Niniejszy artykuł nie może być traktowany jako poradnik umożliwiający poprowadzenie każdego innego kanału w omawianym serwisie. Może on być natomiast cenną uskazówką, pozwalającą określić, jakiego typu działania, formy i dodatkowe kanały społecznościowe sprawdzają się w przypadku określonego typu publikowanych treści, a także specyficznej grupy docelowej, czyli widowni.

\section{Bibliografia}

ApyNews, https://apynews.pl/ (dostęp: 04.10.2018).

Archiwum Darwina, https://uww.youtube.com/user/grupafilmowadarwin (dostęp: 04.10.2018).

Best Global Brands 2016 Rankings, http://interbrand.com/best-brands/best-global-brands/2016/ ranking/ (dostęp: 04.10.2018).

Burgess J., Green J., Youtube: wideo online a kultura uczestnictwa, tłum. T. Płudouski, Wydawnictwo Naukowe PWN, Warszawa 2011.

Darwin, https://twitter.com/gfdarwin (dostęp: 04.10.2018).

Darwiniści, https://www.facebook.com/groups/darwinisci/ (dostęp: 04.10.2018).

G.F. Darwin, https://www.youtube.com/channel/UCkPjHTuNd_ycm_29dXM3Nu (dostęp: 04.10.2018).

Grupa Filmowa Darwin, https://patronite.pl/darwin (dostęp: 04.10.2018).

Kalinouska A., Pieńkouski M., YouTube, czyli nowa forma życia, „Rzeczpospolita” 2015, nr 195.

Kall J., Sojkin B., Zarzadzanie produktem: kreowanie marki, Wydawnictwo Uniwersytetu Ekonomicznego, Poznań 2010.

Patronite, https://patronite.pl (dostęp: 04.10.2018).

Zapytaj Beczkę, https://www.youtube.com/user/TheBeeczka (dostęp: 04.10.2018). 